\title{
HYGIENIC AND ECOLOGICAL ASSESSMENT OF THE MICROCLIMATE IN A FARM FOR INTENSIVE BREEDING OF RABBITS
}

\author{
Diyana Dermendzhieva ${ }^{1}$, Gergana Kostadinova ${ }^{1}$, Georgi Petkov ${ }^{1}$, Toncho Dinev ${ }^{2}$, Vasil Vasilev ${ }^{3}$ \\ ${ }^{I}$ Trakia University, Faculty of Agriculture, Department of Applied Ecology and Animal Hygiene, \\ 6000 Stara Zagora, Bulgaria \\ ${ }^{2}$ Trakia University, Faculty of Agriculture, Department of Biochemistry, Microbiology and Physics, \\ 6000 Stara Zagora, Bulgaria \\ ${ }^{3}$ Agricultural Institute, 6000 Stara Zagora, Bulgaria \\ d.dermendjieva@abv.bg
}

\begin{abstract}
The aim of this study was to investigate the microclimate and to assess its hygienic and ecological properties (temperature $/ T-{ }^{\circ} \mathrm{C}$, relative humidity $/ \mathrm{RH}-\%$, air velocity/AV $-\mathrm{m} / \mathrm{s}, \mathrm{NH}_{3}-\mathrm{mg} / \mathrm{m}^{3}, \mathrm{H}_{2} \mathrm{~S}-\mathrm{mg} / \mathrm{m}^{3}$, total dust $/ \mathrm{TD}-$ $\mathrm{mg} / \mathrm{m}^{3}$ and aerobic plate count/APC $\left(\times 10^{3} \mathrm{CFU} / \mathrm{m}^{3}\right)$ in a farm for intensive breeding of rabbits. The rabbits (in the amount of 595 units - mating, pregnant, does, fattening) were reared in cages, in a building $\left(494 \mathrm{~m}^{2}\right)$ with 4 rooms: $\mathrm{I}^{\text {st }}$ $-218 \mathrm{~m}^{2}, \mathrm{II}^{\mathrm{nd}}-134 \mathrm{~m}^{2}, \mathrm{III}^{\mathrm{rd}}-77 \mathrm{~m}^{2}$ and $\mathrm{IV}^{\mathrm{th}}-65 \mathrm{~m}^{2}$, for $265,160,100$ and 70 rabbits, respectively. The microclimate parameters were determined for a year, twice per season, on 5 monitoring points (MPs): MP-1, MP-2, MP-3 and MP4, in the middle of each room, and on MP- 5 at $5 \mathrm{~m}$ leeward of the barn. All monitored parameters were determined by Bulgarian State Standard'sand other routine methods. It was found that: a) the barn provides optimal microclimate in terms of $\mathrm{T}\left(16.0-25.0^{\circ} \mathrm{C}\right)$ in winter, spring and autumn, and $\mathrm{RH}(65-70 \%)$ in winter at MP-1, MP-2 and MP-3, and in autumn at MP-3 and MP-4, and non-optimal microclimate in terms of $T$ in summer $\left(>25.0^{\circ} \mathrm{C}\right)$, RH in spring $(<65 \%)$ and summer $(>70 \%)$ and $\mathrm{AV}(>2.0 \mathrm{~m} / \mathrm{s})$ in all seasons; b) the air of all rooms contains significant quantities of $\mathrm{NH}_{3}$ $\left(14.3-41.6 \mathrm{mg} / \mathrm{m}^{3}\right), \mathrm{H}_{2} \mathrm{~S}\left(1.59-7.15 \mathrm{mg} / \mathrm{m}^{3}\right)$, TD $\left(0.36-5.00 \mathrm{mg} / \mathrm{m}^{3}\right)$ and aerobic mesophilic bacteria - AMB (22.0$83.0 \times 10^{3} \mathrm{CFU} / \mathrm{m}^{3}$ ), which requires their standardization and animal hygiene evaluation; c) in summer, the rabbits in Ist premise are exposed to moderate heat stress $\left(\mathrm{THI}=27.8-28.9^{\circ} \mathrm{C}\right)$; d) the working environment air quality (in the barn) meets the requirements for $\mathrm{H}_{2} \mathrm{~S}\left(<7.0 \mathrm{mg} / \mathrm{m}^{3}\right)$ and $\mathrm{TD}$ content $\left(<5.0 \mathrm{mg} / \mathrm{m}^{3}\right)$ and deviates from them on $\mathrm{NH}_{3}$ content $\left(>14.0 \mathrm{mg} / \mathrm{m}^{3}\right)$; e) ambient air quality (at MP-5) doesn't meet the $\mathrm{NH}_{3}\left(>0.1 \mathrm{mg} / \mathrm{m}^{3}\right), \mathrm{H}_{2} \mathrm{~S}\left(>0.003 \mathrm{mg} / \mathrm{m}^{3}\right)$ and $\mathrm{TD}\left(>0.25 \mathrm{mg} / \mathrm{m}^{3}\right)$ content requirements; $\left.\mathrm{f}\right)$ the working environment and ambient air contain significant quantities of $\mathrm{TD}$ and $\mathrm{AMB}$, which requires their standardization and hygienic and ecological assessment, respectively.
\end{abstract}

Key words: rabbits; barn; microclimate parameters; hygienic/ecological assessment

\section{ХИГИЕНСКА И ЕКОЛОШКА ОЦЕНА НА МИКРОКЛИМАТА ВО ФАРМА ЗА ИНТЕНЗИВНО ОДГЛЕДУВАЊЕ ЗАЈАЦИ}

Целта на оваа студија беше да се испита и да се направи хигиенска и еколошка оцена на микроклимата (температурата / $T-{ }^{\circ} \mathrm{C}$, релативната влажност / $\mathrm{RH}-\%$, брзината на струењето на воздухот / $\mathrm{AV}-\mathrm{m} / \mathrm{s}, \mathrm{NH}_{3}-$ $\mathrm{mg} / \mathrm{m}^{3}, \mathrm{H}_{2} \mathrm{~S}-\mathrm{mg} / \mathrm{m}^{3}$, вкупната прашина / $\mathrm{TD}-\mathrm{mg} / \mathrm{m}^{3}$ и аеробните мезофилни бактерии / $\mathrm{AMB}\left(\times 10^{3} \mathrm{CFU} / \mathrm{m}^{3}\right)$ во фарма за интензивно одгледување зајаци. Зајаците (вкупно 595 единки - парење, бременост, гоење) беа одгледувани во кафези во зграда $\left(494 \mathrm{~m}^{2}\right)$ со 4 простории: I-та $218 \mathrm{~m}^{2}$, II-та $134 \mathrm{~m}^{2}$, III-та $77 \mathrm{~m}^{2}$ и IV-та $65 \mathrm{~m}^{2}$, за $265,160,100$ и 70 зајаци, соодветно. Параметрите за микроклимата беа одредувани во периодот од една година, двапати во сезоните во 5 точки на мониторингот (MPs): MP-1, MP-2, MP-3 и MP-4 во средината на одделните простории, а МР-5 на 5 метри оддалеченост од натстрешницата на шталата. Сите следени параметри беа утврдени според Бугарскиот државен стандард и други рутински методи. Се покажа дека: а) шталата обезбедува оптимална микроклима во однос на $T\left(16,0-25,0^{\circ} \mathrm{C}\right)$ во зима, пролет и есен и $\mathrm{RH}(65-70 \%)$ во зима во MP-1, MP-2 и MP-3, и во есен во МР-3 и MP-4, а неоптимална микроклима во однос на $T$ во лето $\left(>25,0^{\circ} \mathrm{C}\right)$, $\mathrm{RH}$ во пролет $(<65 \%)$ и лето $(>70 \%)$ и $\mathrm{AV}(>2,0 \mathrm{~m} / \mathrm{s})$ во сите сезони; б) воздухот од сите простории содржи значително количество $\mathrm{NH}_{3}\left(14,3-41,6 \mathrm{mg} / \mathrm{m}^{3}\right), \mathrm{H}_{2} \mathrm{~S}\left(1,59-7,15 \mathrm{mg} / \mathrm{m}^{3}\right), \mathrm{TD}\left(0,36-5.00 \mathrm{mg} / \mathrm{m}^{3}\right)$ и AMB $(22,0-83,0$ $\left.\times 10^{3} \mathrm{CFU} / \mathrm{m}^{3}\right)$, поради што е потребна нивна стандардизација и оцена на хигиената на животните; в) зајаците 
во I-та просторија во текот на летото се изложени на умерен топлотен стрес $\left(\mathrm{THI}=27,8-28,9^{\circ} \mathrm{C}\right)$; г) квалитетот на воздухот во работната средина (во шталата) ги задоволува барањата за $\mathrm{H}_{2} \mathrm{~S}\left(<7,0 \mathrm{mg} / \mathrm{m}^{3}\right)$ и содржината на TD $\left(<5,0 \mathrm{mg} / \mathrm{m}^{3}\right)$, а од стандардите отстапува содржината на $\mathrm{NH}_{3}\left(>14,0 \mathrm{mg} / \mathrm{m}^{3}\right)$; д) квалитетот на амбиенталниот воздух (во МР-5) не ги задоволува барањата за содржина на $\mathrm{NH}_{3}\left(>0.1 \mathrm{mg} / \mathrm{m}^{3}\right), \mathrm{H}_{2} \mathrm{~S}(>0.003$ $\left.\mathrm{mg} / \mathrm{m}^{3}\right)$ и $\mathrm{TD}\left(>0.25 \mathrm{mg} / \mathrm{m}^{3}\right)$; ז́) работното опкружување и амбиентналниот воздух содржат значително количество TD и AMB, коешто бара нивна стандардизација и хигиенска и еколошка оцена, соодветно.

Клучни зборови: зајаци; простории; микроклиматски параметри; хигиенско/еколошки оцени

\section{INTRODUCTION}

In recent years, the intensive production of rabbit meat in many countries of the world is a good alternative to other sectors of the livestock. In comparison to common livestock species the advantages of rabbits are in three main directions. One of them concerns the rabbit's biology: small body size, early age of sexual maturity (4-5 months), efficient reproductive ability, short fattening period, diets from fibrous plant materials and food by-products (ElRaffa, 2004). The second direction concerns the productive parameters of the rabbit: high meat yield, good meat to bone ratio, quality meat with high level of dietary protein, low fat (triglycerides and cholesterol) and energy values, higher quantity of minerals than other meats (Schlolaut, 1992). The third direction is connected with the housing of rabbits: limited cost of the animals and housing facilities, needless land than farms for other animals, easy to transport and market, etc. (Lukefahr and Cheeke, 1991; Colin and Lebas, 1996). According to Kumar et al. (2008) the design of rabbit housing is governed by the behavioural characteristics of the animals and their reactions to environmental temperature and humidity.

Notwithstanding the above mentioned advantages the effective production of rabbit products is faced with many problems, because the rabbits are very sensitive to environmental changes. Maintaining optimum microclimate in the production buildings is one of them. It is well known that for optimal productivity, an animal production system should be capable to provide an appropriate microclimate, i.e. optimal air temperature, relative humidity and air velocity, and low levels of noxious gases $\left(\mathrm{NH}_{3}, \mathrm{H}_{2} \mathrm{~S}\right)$, dust and microorganisms (Marina, 1992; Fisher, 1994). The interaction between air temperature, relative humidity and air velocity in the rabbit barns is the main microclimatic factor which affects energy intake, heat production and the efficiency of rabbit production. Ogunjimi et al. (2008) emphasized that a combination of high temperature and high relative humidity is very stressful and detrimental to rabbit's body thermoregulation and productivity.
Airborne contaminants in the rabbit's barns may originate from animals (fur, epidermal material), their waste (faeces, urine), and materials used in their maintenance (feed, bedding, disinfectants). In a rabbit barn, $\mathrm{NH}_{3}$ and $\mathrm{H}_{2} \mathrm{~S}$ are produced from the degradation of the rabbit's urine and excrement. The degradation process is accelerated under high temperatures (Praag et al., 2010). Under high $\mathrm{NH}_{3}$ concentrations in the air, rabbits can suffer anorexia, breathing issues, cyanosis, fever (Makarenko et al., 1992) and high mortality (Smith et al., 2004). However, there are several other factors with possible health consequences, such as exposure to different airborne contaminants. They may affect the respiratory tract of the animals bred and the personnel and include total and respiratory dust, ammonia, endotoxins, bacteria and fungi. All of these occur at high ionic concentrations in the air of farm livestock buildings (Preller et al., 1995). Pathogenic bacteria, viruses and fungi may also exist in the air of rabbit units, causing a possible risk for animals and personnel. In this regard El-Raffa (2004) argued that disease prevention is very important in rabbit production. The author proposes to develop and implement careful hygiene program in the growing of rabbits in which the preventive hygiene is a key to effectively control any disease which might break out. Preventive hygiene is usually enough to prevent major disease crises. Daily preventive cleaning will keep the contamination and pollution levels down and make the rabbitry viable and productive for longer period. Many authors (Ramchurn, 1979; Finzi and Amici, 1991; Habeeb et al., 1993; Kacergis et al., 1996) consider that good housing means good rabbits health.

Flores-Velázquez et al. (2017) point out that in Central Mexico, rabbit barns have been installed in pre-existing naturally vented buildings, where high concentrations of $\mathrm{NH}_{3}$ and high air temperatures seriously limit production, especially during the hottest part of the year. An alternative to control the microclimate of these barns is through mechanical ventilation. However, a barn should ensure significantly lower airborne contaminants levels to safeguard the rabbit's welfare. 
In Bulgaria, despite the traditions and good natural and climatic conditions the registered rabbits, which are grown in recent years, are about 52000. The reasons for this unsatisfactory state of rabbit breeding are of a different nature: inadequate professional qualification of rabbit growers, outdated equipment, lack of direct subsidies to farmers, insufficient scientific services of the sector, etc. (ARSDA, 2016).

The aim of this paper was to investigate and to make a hygienic and ecological assessment of the main microclimate parameters in a farm for intensive breeding of rabbits, situated in a region with transcontinental climate of south Bulgaria.

\section{MATERIAL AND METHODS}

Study area. The study was conducted over a period of one year (2015) in the experimental farm for intensive breeding of rabbits at Agricultural Institute, Stara Zagora, a region with altitude 196 m and transcontinental climate with average annual temperature $12.9^{\circ} \mathrm{C}$ (January: average $+1.0^{\circ} \mathrm{C}$, average minimum $-2.1^{\circ} \mathrm{C}$; July: average $+24.0^{\circ} \mathrm{C}$, average maximum $+30.1^{\circ} \mathrm{C}$ ) and an average annual rainfall $598 \mathrm{~mm}$. The 595 rabbits of different categories (mating, pregnant, does and fattening) from White New Zealand and Californian breeds were bred in cages (installed $1.00 \mathrm{~m}$ over the floor) in one production building $\left(55.00 / 9.00 / 3.60 \mathrm{~m}, 494 \mathrm{~m}^{2}\right)$, reconstructed cowshed. The building is divided into four premises: $\mathrm{I}^{\mathrm{st}}-218 \mathrm{~m}^{2}$, II ${ }^{\mathrm{nd}}-134 \mathrm{~m}^{2}, \mathrm{III}^{\mathrm{rd}}-77$ $\mathrm{m}^{2}$ and $\mathrm{IV}^{\mathrm{th}}-65 \mathrm{~m}^{2}$, for $265,160,100$ and $70 \mathrm{rab}-$ bits, respectively (Figure 1).

The building construction design is as follows: walls - brickwork, plastered inside and outside with mortar; ceiling - roof tiles, wood siding, plastered inside with mortar; floor - concrete surface; windows - 12 ( 3 per every premises), placed on the building south wall, wood construction (0.50/1.00 $\mathrm{m})$; doors -2 on the building south wall, wood construction $(2.20 / 2.60 \mathrm{~m})$. The ventilation system is mixed - natural (through windows and doors) and mechanical - by a ventilator (capacity 60000 1/h) mounted in the middle of the south wall of the building. The rabbits were fed twice a day with dry fodder mixtures tailored to the requirements of individual rabbit categories. Water for watering the animals was provided by drip drinkers. Manure was collected on the concrete floor beneath cages and was cleaned manually every day.

Monitoring points (MPs). Inside and outside of the barn 5 monitoring points (MPs) for sampling air were identified, as follows (Figure 1):
- Inside: MP-1, MP-2, MP-3 and MP-4, over the servicing trail in the relevant premises of the building, respectively $\mathrm{I}^{\mathrm{st}}$, II ${ }^{\text {nd }}$, III ${ }^{\mathrm{rd}}$ and IV $^{\text {th }}$.

- Outside: MP-5 at $5.00 \mathrm{~m}$ from the leeward side of the building.

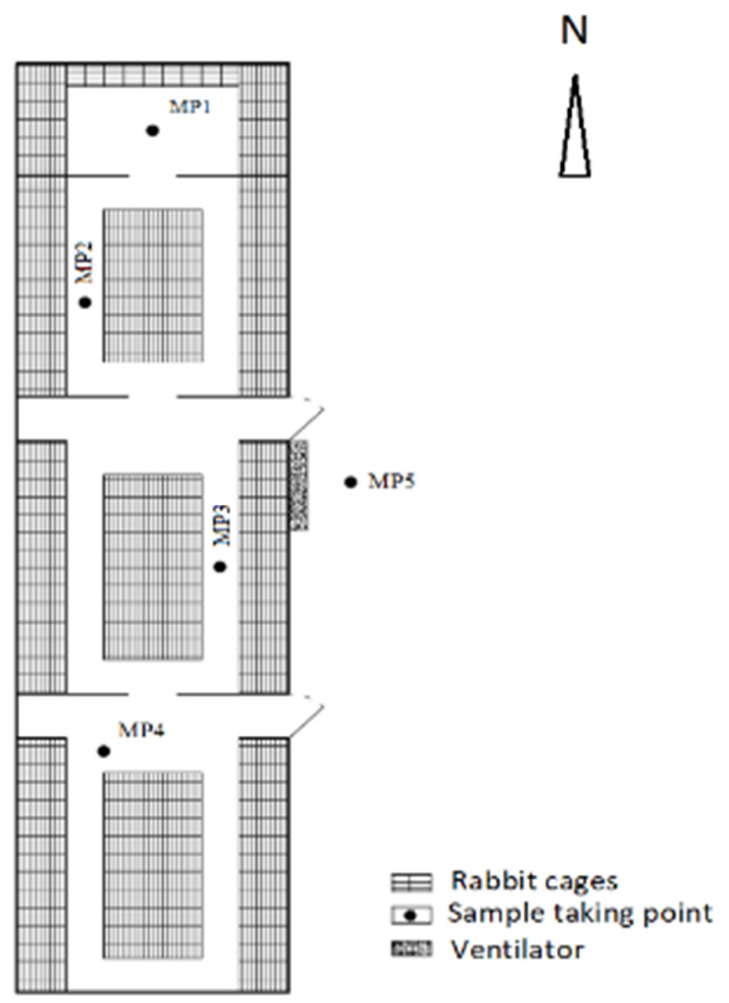

Fig. 1. Scheme of the longitudinal section of the rabbit's barn

Microclimate parameters and methods for determination. The following microclimate parameters were measured, once per two months between 10.00 and 12.00 AM of the day, at a height of 1.00 $\mathrm{m}$ from the floor/ground surface:

- Physical parameters in situ: Air temperature $\left(T,{ }^{\circ} \mathrm{C}\right)$ and relative humidity $(\mathrm{RH}, \%)$ - by a combined instrument ,Lutron MCH-383SDB” with a range for temperature from 0 to $50{ }^{\circ} \mathrm{C}$ and for $\mathrm{RH}$ from 10 to $100 \%$, respectively; air velocity (AV, $\mathrm{m} / \mathrm{s}$ ) - by the combined instrument ,Lutron EM9300SD" with diapason between 0.1 and $25 \mathrm{~m} / \mathrm{s}$.

- Chemical parameters: Ammonia $\left(\mathrm{NH}_{3}\right.$, $\mathrm{mg} / \mathrm{m}^{3}$ ) - by titrimetric method with $\mathrm{HCl}$ (Balanin, 1979); hydrogen sulfide $\left(\mathrm{H}_{2} \mathrm{~S}, \mathrm{mg} / \mathrm{m}^{3}\right)$ - by titrimetric method with $\mathrm{NaOH}$ (Balanin, 1979); total dust (TD, $\mathrm{mg} / \mathrm{m}^{3}$ ) - by gravimetric method (Bulgarian State Standard 17.2.4.20-83). 
- Microbiological parameters: Aerobic mesophilic bacteria - AMB $\left(\times 10^{3} \mathrm{CFU} / \mathrm{m}^{3}\right.$ air $)$ - by sedimentation method of Matusevich (1975, quoted by Petkov et al., 1999). Briefly the essence of the method is as follows: at any MP were taken two parallel samples, using Petri dishes with Nutrient Agar $\left(\mathrm{BBL}^{\mathrm{TM}}, \mathrm{USA}\right)$; the sampling was performed in sterile cardboard cylinders of 1 liter which was placed on sterile Petri dishes and the other side of the cylinder was covered with the lid of the Petri dish; the cylinders remained in vertical position for 15 min, during which time the microorganisms from air sample sedimented on the agar medium; after that, cardboard cylinders were removed and Petri dishes were covered with their lids; the plated Petri dishes were transported to the microbiological laboratory in a cool bag (at $4-6^{\circ} \mathrm{C}$ ) and were incubated for 2 days at $37 \pm 1.0{ }^{\circ} \mathrm{C}$. The colonies were counted as colony forming units $\left(\mathrm{CFU} / \mathrm{m}^{3}\right)$.

- Temperature-humidity index (THI): It is used as an indicator of thermal comfort level for animals and was calculated according to LPHSI (1990) with modification for rabbit equation by Marai et al. (2002):

$$
\mathrm{THI}=\mathrm{t}-[(0.31-0.31 \times \mathrm{RH}) \cdot(t-14.4)],
$$

where:

RH is relative humidity $(\%) / 100$.

The values of THI are classified as follow:

$-<27.8^{\circ} \mathrm{C}=$ absence of heat stress;

- $27.8-28.9^{\circ} \mathrm{C}=$ moderate heat stress;

- $28.9-30^{\circ} \mathrm{C}=$ severe heat stress;

- above $30^{\circ} \mathrm{C}=$ very severe heat stress.

Methods for hygienic assessment of microclimatic parameters. A method of comparative analysis was used, in which the results obtained were compared with the hygienic norms for air quality stipulated in Bulgarian legislation in three directions as follow:

- Animal hygiene assessment of microclimate in the barn: according to Regulation No. 44 (2006) for veterinary medical requirements to animal holding.

- Air quality in the work environment (in the barn): according to Regulation No. 13 (2003) - to protect workers from the risks related to exposure to chemical agents at work.

- Ambient air quality (outside the barn): according to Regulation No. 14 (1997) - norms for maximum permissible concentrations of harmful substances in the air of settlements.
Determination of the synergistic effect of the simultaneous presence in the air of $\mathrm{NH}_{3}$ and $\mathrm{H}_{2} \mathrm{~S}$ according to formula (Regulation No. 14, 1997; Regulation No. 13, 2003):

$$
C_{1} / C_{2}=\mathrm{NH}_{3(1 / 2)} / P L_{\mathrm{NH}_{3}(1 / 2)}+\mathrm{H}_{2} \mathrm{~S}_{(1 / 2)} / P L_{\mathrm{H}_{2} \mathrm{~S}(1 / 2)} \leq 1,
$$

where:

$C_{1}$ and $C_{2}$ are the coefficient values for air quality of the working environment $\left(C_{1}\right)$ and for outside air $\left(C_{2}\right)$, respectively;

$\mathrm{NH}_{3(1 / 2)}$ - concentration $\left(\mathrm{mg} / \mathrm{m}^{3}\right)$ in the barnworking environment (1) and in outside air (2);

$P L_{\mathrm{NH}_{3}(1 / 2)}$ - permitted limit for $\mathrm{NH}_{3}$ concentration $\left(\mathrm{mg} / \mathrm{m}^{3}\right)$ in the barn-working environment $(1$, $\left.14.0 \mathrm{mg} / \mathrm{m}^{3}\right)$ and in outside air $\left(2,0.1 \mathrm{mg} / \mathrm{m}^{3}\right)$;

$P L_{\mathrm{H}_{2} \mathrm{~S}(1 / 2)}$ - permitted limit for $\mathrm{H}_{2} \mathrm{~S}$ concentration $\left(\mathrm{mg} / \mathrm{m}^{3}\right)$ in the barn-working environment $(1$, $\left.7.0 \mathrm{mg} / \mathrm{m}^{3}\right)$ and in outside air $\left(2,0.003 \mathrm{mg} / \mathrm{m}^{3}\right)$.

Statistical analysis. The data were processed and the figures were performed by using Excel (Microsoft Office 2007) and Statistica 6.1 (Statistica for Windows, Statsoft. Inc., Tulsa, OK, USA, 19842002).

\section{RESULTS AND DISCUSSION}

\section{Animal hygiene assessment of microclimate}

Air temperature. The temperature values did not differ significantly between the different MPs in the building (Table 1).

For average temperatures the variance between the largest and lowest value was $1.4^{\circ} \mathrm{C}$, for minimum $2.1^{\circ} \mathrm{C}$ and for maximum $2.4^{\circ} \mathrm{C}$, respectively. More pronounced were the differences between inside (MP-1, MP-2, MP-3, MP-4) and outside air temperature (MP-5): for average values $1.7-3.1^{\circ} \mathrm{C}$, for minimum $4.0-6.1^{\circ} \mathrm{C}$ and for maximum $0.1-$ $2.5^{\circ} \mathrm{C}$. All values of the air temperature in the barn were in the optimal range for rabbits $\left(16.0-25.0^{\circ} \mathrm{C}\right)$, according to Regulation No. 44 (2006). Exceptions were the temperatures in the summer when across all MPs in the building the values were higher $\left(26.3-29.4^{\circ} \mathrm{C}\right)$ than the upper permitted limit. Damyanova and Derebanov (1975) recommended wider range of the optimum temperature for rabbits $\left(8.0-25.0^{\circ} \mathrm{C}\right)$, but with respect to the lower permitted limit. Kumar et al. (2008) noted that the air temperature over $30^{\circ} \mathrm{C}$ suppresses the reproductive ability of rabbits. Such an effect would be expected only in does at the $\mathrm{I}^{\mathrm{st}}$ and $\mathrm{II}^{\text {nd }}$ premises where the temperatures were close to $30^{\circ} \mathrm{C}$. 
Table 1

Average, minimum and maximum values of the investigated microclimate parameters by monitoring points

\begin{tabular}{|c|c|c|c|c|c|c|}
\hline \multirow{3}{*}{ Parameters } & \multirow{3}{*}{$n=6$} & \multicolumn{5}{|c|}{ Monitoring points } \\
\hline & & \multicolumn{4}{|c|}{ Inside the building } & \multirow{2}{*}{$\begin{array}{l}\text { Outside the building } \\
\text { MP-5 }\end{array}$} \\
\hline & & MP-1 & MP-2 & MP-3 & MP-4 & \\
\hline \multirow{3}{*}{$\begin{array}{l}T \\
{ }^{\circ} \mathrm{C}\end{array}$} & Mean \pm SD & $23.1 \pm 4.45$ & $22.6 \pm 4.03$ & $21.7 \pm 4.78$ & $21.8 \pm 4.13$ & $24.8 \pm 5.59$ \\
\hline & $\min$ & 12.2 & 11.4 & 10.1 & 10.2 & 6.1 \\
\hline & $\max$ & 29.2 & 28.5 & 27.6 & 26.8 & 29.3 \\
\hline \multirow{3}{*}{$\begin{array}{l}\text { Relative humidity, } \\
\%\end{array}$} & Mean \pm SD & $75.0 \pm 12.7$ & $77.1 \pm 12.4$ & $80.5 \pm 11.3$ & $80.5 \pm 11.1$ & $69.0 \pm 15.6$ \\
\hline & $\min$ & 58.3 & 59.1 & 67.3 & 64.7 & 48.9 \\
\hline & $\max$ & 93.0 & 89.1 & 94.6 & 98.9 & 87.3 \\
\hline \multirow{3}{*}{$\begin{array}{l}\text { Air velocity, } \\
\mathrm{m} / \mathrm{s}\end{array}$} & $\mathrm{Mean} \pm \mathrm{SD}$ & $0.45 \pm 0.29$ & $0.38 \pm 0.23$ & $0.29 \pm 0.05$ & $0.26 \pm 0.11$ & $0.51 \pm 0.16$ \\
\hline & $\min$ & 0.28 & 0.12 & 0.23 & 0.18 & 0.33 \\
\hline & $\max$ & 0.71 & 0.68 & 0.34 & 0.42 & 0.68 \\
\hline \multirow{3}{*}{$\begin{array}{l}\mathrm{NH}_{3} \\
\mathrm{mg} / \mathrm{m}^{3}\end{array}$} & Mean \pm SD & $18.9 \pm 0.93^{\mathrm{ac}}$ & $37.8 \pm 2.82^{\mathrm{cd}}$ & $19.1 \pm 5.78$ & $30.5 \pm 4.16^{\mathrm{ab}}$ & $16.1 \pm 0.18^{\mathrm{bd}}$ \\
\hline & $\min$ & 18.3 & 35.2 & 14.3 & 27.5 & 13.9 \\
\hline & $\max$ & 20.3 & 41.6 & 27.4 & 36.6 & 18.7 \\
\hline \multirow{3}{*}{$\begin{array}{l}\mathrm{H}_{2} \mathrm{~S} \\
\mathrm{mg} / \mathrm{m}^{3}\end{array}$} & Mean \pm SD & $3.70 \pm 1.83$ & $5.83 \pm 1.08^{\mathrm{a}}$ & $4.02 \pm 1.16$ & $2.84 \pm 1.39$ & $2.51 \pm 0.75^{\mathrm{a}}$ \\
\hline & $\min$ & 2.39 & 4.62 & 2.93 & 1.59 & 1.39 \\
\hline & $\max$ & 6.39 & 7.15 & 5.54 & 4.62 & 2.87 \\
\hline \multirow{3}{*}{$\begin{array}{l}\text { Total dust, } \\
\mathrm{mg} / \mathrm{m}^{3}\end{array}$} & Mean \pm SD & $1.00 \pm 0.38$ & $1.31 \pm 0.26$ & $1.95 \pm 1.36$ & $1.51 \pm 0.73$ & $0.67 \pm 0.43$ \\
\hline & $\min$ & 0.49 & 1.02 & 0.36 & 0.98 & 0.14 \\
\hline & $\max$ & 1.37 & 1.65 & 5.00 & 2.54 & 1.16 \\
\hline \multirow{3}{*}{$\begin{array}{l}\text { Aerobic mesophilic } \\
\text { bacteria, } \\
\mathrm{CFU} / \mathrm{m}^{3}\left(\times 10^{3}\right)\end{array}$} & Mean \pm SD & $47.1 \pm 18.3$ & $74.5 \pm 9.9$ & $42.0 \pm 14.5$ & $52.4 \pm 23.2$ & $35.1 \pm 17.9$ \\
\hline & $\min$ & 31.0 & 61.5 & 28.0 & 22.0 & 19.5 \\
\hline & $\max$ & 62.5 & 83.0 & 55.5 & 75.0 & 55.0 \\
\hline
\end{tabular}

*Differences in the values by rows are significant at: $P<0.05-\mathrm{aa}, \mathrm{bb} ; P<0.01-\mathrm{cc} ; P<0.001-\mathrm{dd}$.

It is noteworthy that in summer the air temperature in all MPs in the barn were lower than outside temperature. This can be explained by the design and the construction materials used to build the barn, which provides good protection against solar radiation in the summer months. Kumar et al. (2008) reported similar trend in the summer regarding cage reared rabbits in conventional rabbit houses in India. The authors established negative temperature gradient between outside and inside air temperature in the order of $0.3-0.9^{\circ} \mathrm{C}$.

Relative humidity $(\boldsymbol{R H})$. Indicator's values showed a higher dynamics of variation as compared to the air temperature. In the MPs in the barn the difference in mean relative humidity was $5.5 \%$, at minimum $9.0 \%$ and at maximum $9.8 \%$, respectively. More pronounced, but not statistically significant were the differences between inside and outside RH: for average values $6.0-11.5 \%$, for minimum $9.4-18.4 \%$ and for maximum $0.8-10.6 \%$. Only a small part of the measured values of RH in the barn were in the optimal range by Regulation No. 44 (2006) - 65-70\%: in winter at MP-1, MP-2 and MP-3, and in autumn at MP-3 and MP-4. Higher than the norm were the values in winter at MP-3 and MP-4; in spring at all MPs and in summer at MP-2, MP-3 and MP-4. Lower than the norm were the values in summer at MP- 1 and MP-5, and in autumn at MP-1, MP-2 and MP-5. The uneven distribution of $\mathrm{RH}$ in the air of different premises of the barn indicates that the ventilation system is not working effectively, especially in winter and summer.

Some authors defined a wider range of the optimum RH in the rabbit's barns (60-80\% - Damyanova and Derebanov, 1975; 60-75\% - Utkin, 1987; 80-86\% - Nguyen Quang Suc, 1985, quoted by Kumar et al., 2008), which is more realistic than the Bulgarian standard. In the evaluation of this parameter should always be taken into account the air temperature, since their combining at different values affect differently the rabbit's organism.

Temperature-humidity index (THI). Thermal comfort level of rabbits, evaluated by THI shows that in II $^{\text {nd }}(\mathrm{MP}-2)$, III ${ }^{\text {rd }}$ (MP-3) and IV $^{\text {th }}$ (MP-4) premises there is absence of heat stress (THI values 
$<27.8^{\circ} \mathrm{C}$ ) (Table 2). The rabbits are subjected to moderate heat stress only in $\mathrm{I}^{\text {st }}$ (MP-1) premises, where the air temperature was between 27.8 and $28.9^{\circ} \mathrm{C}$ (Ogunjimi et al., 2008). Further research is needed to verify the design of rabbit facilities which will provide an all year round thermally conducive environment for the rabbit's productivity.

Table 2

Temperature-humidity index (THI) values in summer 2015 by monitoring points in the production building

\begin{tabular}{lccc}
\hline $\begin{array}{l}\text { Monitoring } \\
\text { points }\end{array}$ & $\begin{array}{c}\text { Air } \\
\text { temperature, } \\
{ }^{\circ} \mathrm{C}\end{array}$ & $\begin{array}{c}\text { Relative } \\
\text { humidity, } \\
\%\end{array}$ & $\begin{array}{c}\text { THI, } \\
{ }^{\circ} \mathrm{C}\end{array}$ \\
\hline MP-1 & 29.2 & 76.3 & 28.2 \\
MP-2 & 28.5 & 85.1 & 27.8 \\
MP-3 & 27.6 & 77.8 & 26.6 \\
MP-4 & 26.8 & 77.7 & 25.8 \\
\hline
\end{tabular}

Air velocity. All measured values of the air velocity in the barn exceed the maximum permissible air velocity according to Regulation No. 44 (2006) $-<0.2 \mathrm{~m} / \mathrm{s}$ (from 1.30 to 2.25 times for average and from 1.70 to 3.55 times for maximum values). Exceptions were two MPs - MP-2 in spring and MP-4 in summer, where air velocity was in the norm. The results obtained are slightly lower than the results reported by Kumar et al. (2008) for conventional rabbit sheds $(0.61-0.81 \mathrm{~m} / \mathrm{s})$ in India. In respect of maximum permissible air speed in the rabbit's barns Damyanova and Derebanov (1975) and Utkin (1987) considered that it may be up to $3.0 \mathrm{~m} / \mathrm{s}$, while Morisse (1981, quoted by Kumar et al., 2008) recommended an air speed of 0.30 to $0.40 \mathrm{~m} / \mathrm{s}$ at a temperature of 22 to $25^{\circ} \mathrm{C}$.

Differences in air velocity between MPs in the barn - on the one hand and between inside MPs and outside MP - on the other hand, are well marked, but not statistically significant. The indicator can be evaluated both independently (higher air velocity in the barn, more dust and microorganisms in the air) and in combination with the temperature and humidity of the air (influence on rabbit body thermoregulation).

Ammonia. Air ammonia levels in the barn were between $18.3 \mathrm{mg} / \mathrm{m}^{3}$ at MP-1 and $41.6 \mathrm{mg} / \mathrm{m}^{3}$ at MP-2. The differences between the MPs are well marked and in some cases statistically significant (between MP-1 and MP-2 at P $<0.001 ; \mathrm{MP}-1$ and MP-4 at $P<0.05$; MP-2 and MP-5 at $P<0.001$; MP-4 and MP-5 at $P<0.01$, respectively). Since in Bulgarian legislation there is no norm for this indicator, the assessment was made on standards of other countries or recommended by other authors Russia, up to $10.0 \mathrm{mg} / \mathrm{m}^{3}$ (Utkin, 1987); up to 20.0 $\mathrm{mg} / \mathrm{m}^{3}$ (Damyanova and Derebanov, 1975) and up to $18.0 \mathrm{mg} / \mathrm{m}^{3}$ (Perkins and Lipman, 1995). All the measured ammonia concentrations were higher than the above suggested norms. Particularly worrying were the air ammonia content in MP-2 (II ${ }^{\text {nd }}$ premises) and MP-4 (IV ${ }^{\text {th }}$ premises). Bearing in mind that the waste is cleaned daily in the building, uneven and above the norms concentrations of $\mathrm{NH}_{3}$ in the different premises are indirect evidence of inefficient operation of the ventilation system. Apparently, $\mathrm{NH}_{3}$ is a problem for the adopted rabbits breeding system.

Hydrogen sulfide. The parameter values varied within a wide range $\left(1.59-7.15 \mathrm{mg} / \mathrm{m}^{3}\right)$ inside and in a significantly narrow range (1.39 $2.87 \mathrm{mg} / \mathrm{m}^{3}$ ) outside the building. The differences in $\mathrm{H}_{2} \mathrm{~S}$ concentration between all MPs are well defined, but not statistically significant, with one exception between MP-2 and MP-5 $(P<0.05)$. This indicator has no norm in Bulgarian legislation. The parameter was not commented often in the scientific literature for rabbits. We believe that this indicator should not be underestimated, because this gas is not only harmful but also very toxic. These properties are enhanced in the presence of ammonia in the air, which brings about a synergetic effect.

Total dust (TD). The total dust levels in the air of the controlled MPs fluctuated over a very wide diapason $\left(0.36-5.00 \mathrm{mg} / \mathrm{m}^{3}\right)$ - the range is 13.9 times. By MPs in the barn the dust quantity demonstrated significant dynamics. The differences between the maximum and minimum values are 1.95 times for the average values, 2.83 times for minimum and 3.65 times for maximum values, respectively. Dust content in the outside air, at $5 \mathrm{~m}$ from the building (MP-5) was 1.18 to 7.28 times lower than that in the building, but the influence of the air dust emission from the building on the outside air in the test zone is well expressed. This indicator is not standardized in Bulgarian legislation. We also did not find information on the issue in the accessible literature. For this reason assessment of air quality in the studied building on the base of TD content was not made. Accumulation of more scientific information is necessary in order to substantiate relevant standards for dust in the air of rabbit's barns. 
Aerobic mesophilic bacteria (AMB). The total concentrations of AMB in the barn were between $22.0 \times 10^{3} \mathrm{CFU} / \mathrm{m}^{3}$ at MP- 4 and $83.0 \times 10^{3} \mathrm{CFU} / \mathrm{m}^{3}$ at MP-2, while in the outside air (MP-5) it was from $19.5 \times 10^{3} \mathrm{CFU} / \mathrm{m}^{3}$ to $55.0 \times 10^{3} \mathrm{CFU} / \mathrm{m}^{3}$. The average values in barn MPs are relatively equalized with the exception of MP-2, wherein the number of bacteria is considerably larger (from 1.41 to 1.77 times). However, these values are much higher those reported from Kaliste et al. (2002) for conventional laboratory rabbit rooms $\left(6400-9000 \mathrm{CFU} / \mathrm{m}^{3}\right)$ and well below for other animal facilities, such as poultry buildings $\left(84.0-265.0 \times 10^{3} \mathrm{CFU} / \mathrm{m}^{3}\right.$, Kostadinova et al., 2014) or swine buildings - for sows and litters $\left(89.0-428.0 \times 10^{3} \mathrm{CFU} / \mathrm{m}^{3}\right)$ and for fattening pigs $\left(13.0-120.0 \times 10^{3} \mathrm{CFU} / \mathrm{m}^{3}\right)$ (Petkov et al., 2010). Average AMB values at MP-5 (outside the barn) was 1.12 to 2.12 times lower than in the building, but remained relatively high. For this indicator, there is no norm, which is why animal hygiene assessment cannot be done. Dennis (1999) reported that opportunistic pathogens and zoonotic microrganisms may also be present in the air. For all these reasons, airborne contaminants should be considered as potential residential health risks both for farm animals bred and for the personnel and appropriate monitoring and preventive measures have to be adopted.

Air quality in the work environment (in the barn). This assessment was made on the base of three indices $-\mathrm{NH}_{3}, \mathrm{H}_{2} \mathrm{~S}$ and TD content, included in Regulation No. 13 (2003). The levels of these parameters in the rabbit premises were: for $\mathrm{NH}_{3}$ from 1.02 to 2.97 times higher than the permissible limit (up to $14.0 \mathrm{mg} / \mathrm{m}^{3}$ ), for $\mathrm{H}_{2} \mathrm{~S}$ from 4.40 times lower to 1.02 times higher than the permissible limit (up to $7.0 \mathrm{mg} / \mathrm{m}^{3}$ ) and for TD 13.9 times lower than the limit value (up to $5.0 \mathrm{mg} / \mathrm{m}^{3}$ ). With regard to ammonia, U.S. and Finnish regulation indicates that workplace exposure to ammonia should not exceed $25 \mathrm{ppm}\left(=19 \mathrm{mg} / \mathrm{m}^{3}\right)$ during an 8-hour period (NIOSH, 2011). Perkins and Lipman (1995) recommended these standards should also be applied to animal environments. Since the rabbits are exposed to ammonia $24 \mathrm{~h}$ every day, a constant source of $\mathrm{NH}_{3}$ lower than $25 \mathrm{ppm}$ was simulated to estimate the spatial distribution of this gas. Concerning the total dust, Donham et al. (1995) suggested that concentrations of TD $<2.8 \mathrm{mg} / \mathrm{m}^{3}$ (as in our case, with the exception of MP-3, where the maximum value is $5.00 \mathrm{mg} / \mathrm{m}^{3}$ ), does not significantly affect the pulmonary FEV1 (forced expiratory volume/s) at farm workers. According to this criterion the dust levels in the rabbit premises were unlikely to be a great health risk.

Since in the air of the barn was found the presence of both $\mathrm{NH}_{3}$ and $\mathrm{H}_{2} \mathrm{~S}$, the assessment was made by that composite coefficient $\left(C_{1}\right)$, calculated by formula according to Regulation No. 13 (2004). The results showed that in all MPs in the building the calculated coefficient values $\left(C_{1}\right)$ were between 1.77 at MP-1 in the winter and 3.74 at MP-2 in the summer, i.e. all values of were over the permitted limit $\left(C_{1} \leq 1\right.$, suggesting a synergistic effect of the two gases. Therefore, there is a potential health risk for the personnel.

Ambient air quality. The assessment of the outside air quality was made on $\mathrm{NH}_{3}, \mathrm{H}_{2} \mathrm{~S}$ and TD content according to Regulation No. 14 (1997). The concentrations of these parameters in outside air, at $5.0 \mathrm{~m}$ from the barn (MP-5), were higher by the relevant daily average limit value $(0.1,0.003$ and 0.25 $\mathrm{mg} / \mathrm{m}^{3}$ ) as follows: for $\mathrm{NH}_{3}$ from 139 times in winter to 187 times in spring, for $\mathrm{H}_{2} \mathrm{~S}$ from 463.3 times in winter to 956.7 times in summer, and for TD from 1.52 times in autumn to 4.64 times in spring. Only in the winter the TD levels were in the norm $(0.14$ $\mathrm{mg} / \mathrm{m}^{3}$ )

Assessment of ambient air quality was made also by composite coefficient $\left(C_{2}\right)$ for the determination of the synergistic effect of the simultaneous presence in the air of $\mathrm{NH}_{3}$ and $\mathrm{H}_{2} \mathrm{~S}$, calculated by formula according to Regulation No. 14 (1997). The results showed that $C_{2}$ values were between 602.3 in the winter and 1099.7 in the summer, i.e. they have repeatedly exceeded the exposure limit $\left(C_{2} \leq 1\right)$. Therefore, at distances up to $5 \mathrm{~m}$ from the barn (MP5 ) there is a potential health risk for the personnel.

\section{CONCLUSION}

It was found that: a) the studied reconstructed cowshed, divided into 4 premises, used for cage breeding of rabbits, provides optimal microclimate parameters in terms of temperature $\left(16.0-25.0^{\circ} \mathrm{C}\right)$ in winter, spring and autumn and relative humidity $(65-70 \%)$ in winter at MP-1, MP-2 and MP-3, and in autumn at MP-3 and MP-4, and non-optimal values for temperature in summer $\left(>25.0^{\circ} \mathrm{C}\right)$, for relative humidity in spring $(<65 \%)$ and summer $(>70 \%)$ and for air velocity $(>2.0 \mathrm{~m} / \mathrm{s})$ in all seasons; b) the air of all premises contains significant quantities of $\mathrm{NH}_{3}\left(14.3-41.6 \mathrm{mg} / \mathrm{m}^{3}\right), \mathrm{H}_{2} \mathrm{~S}\left(1.59-7.15 \mathrm{mg} / \mathrm{m}^{3}\right)$, total dust $\left(0.36-5.00 \mathrm{mg} / \mathrm{m}^{3}\right)$ and aerobic mesophilic bacteria $\left(22.0-83.0 \times 10^{3} \mathrm{CFU} / \mathrm{m}^{3}\right)$, which requires their standardization and animal hygiene 
evaluation; c) the working environment air quality (in the barn) meets the requirements for $\mathrm{H}_{2} \mathrm{~S}(<7.0$ $\left.\mathrm{mg} / \mathrm{m}^{3}\right)$ and total dust content $\left(<5.0 \mathrm{mg} / \mathrm{m}^{3}\right)$ and deviates from them on $\mathrm{NH}_{3}$ content $\left.\left(>14.0 \mathrm{mg} / \mathrm{m}^{3}\right) ; \mathrm{d}\right)$ ambient air quality (at $5.0 \mathrm{~m}$ distance from the barn) does not meet the $\mathrm{NH}_{3}\left(>0.1 \mathrm{mg} / \mathrm{m}^{3}\right), \mathrm{H}_{2} \mathrm{~S}(>0.003$ $\left.\mathrm{mg} / \mathrm{m}^{3}\right)$ and total dust $\left(>0.25 \mathrm{mg} / \mathrm{m}^{3}\right)$ content requirements; d) the working environment air and ambient air (up to $5.0 \mathrm{~m}$ from the barn) contains significant quantities of total dust and aerobic mesophilic bacteria, which requires their standardization and hygienic and ecological assessment, respectively.

\section{REFERENCES}

[1] ARSDA - Annual report on the status and development of agriculture: Ministry of Agriculture and Food, Sofia, pp. 52-53 (2016) (Bg).

[2] Balanin, V. I.: Animal hygiene control microclimate in farm animal buildings. Leningrad, Kolos Publ. house, pp. 1642 (1979), (Ru).

[3] Colin, N., Lebas, F.: Rabbit meat production in the world. A proposal for every country. $6^{\text {th }}$ World Rabbit Congress, Toulouse, France, 9-12 ${ }^{\text {th }}$ July, WRSA, 1996, pp. 323-330.

[4] Damjanova, N. V., Derebanov A. S.: Breeding of rabbits, Zemizdat Publ. house, Sofia, 1975, pp. 132-156 (Bg).

[5] Dennis, M. J.: Infectious hazards. In: Health and Safety in Laboratory Animal Facilities, Laboratory Animal Handbooks No. 13 (Wood M, Smith MW, eds), London: The Royal Society of Medicine Press Limited, pp. 49-91.

[6] Donham, K. J., Reynolds, S. J., Whitten, P., Merchant, J. A., Burmeister, L., Popendorf, W. J. (1995): Respiratory dysfunction in swine production facility workers: dose-response relationships of environmental exposures and pulmonary function. Am. J. of Industr. Med., 27, 405-18 (1999).

[7] El-Raffa, A. M.: Rabbit production in hot climate. In.: Proceedings of the $8^{\text {th }}$ World Rabbit Congress, September 7-10, 2004, Puebla, Mexico, pp. 1172-1180, 2004.

[8] Fisher, A.: Hygienic aspects of the microclimate in intensive management of rabbits, Vet. Med., 39 (7), 407-22 (1994).

[9] Flores-Velázquez, J., Villarreal-Guerrero, F., Ojeda, W., Ruíz-García, A.: Thermal and ammonia concentration gradients in a rabbit barn with two ventilation system designs. Revista Brasileira de Engenharia Agrícola e Ambiental, 21 (2), 134-140 (2017).

[10] Finzi, A., Amici, A.: Traditional and alternative rabbit breeding systems for developing countries. Revista di Agricoltura Subtropicale e Tropicales, LXXXV, No. 1: 103-125 (1991).

[11] Habeeb, A. A., Aboul-Naga, A. I., Yousef, H. M.: Influence of exposure to high temperature on daily gain, feed efficiency and blood components of growing male Californian rabbits. Egyptian J. Rabbit Science, 3, 73-80 (1993).

[12] Kacergis, J. B., Jones, R. B., Reeb, C. K., Turner, W. A., Ohman, J. L., Ardman, M. R., Paigen, B.: Air quality in an animal facility: particulates, ammonia, and volatile organic compounds. Am. Ind. Hyg. Assoc. J., 57, 634-640 (1996).

[13] Kaliste E., Linnainmaa M., Meklin T., Nevalainen A.: Airborne contaminants in conventional laboratory rabbit rooms. Lab. Animals, 36, 43 (2002).

[14] Kostadinova, G., Petkov, G., Denev, S., Miteva, C.H., Stefanova, R., Penev, T.: Microbial pollution of manure, litter, air and soil in a poultry farm. Bulg. J. of Agr. Sci., 20 (1), 66-75 (2014).

[15] Kumar, V. R. S., Sivakumar, K., Singh, D. A. P., Ramesh, V., Muralidharan, J., Viswanathan, K.: Development of improvised housing system for commercial rearing of broiler rabbits. Livestock Research for Rural Development, 20 (10), 54-62 (2008).

[16] Lebas, F., Coudert, P., Rouvier, R., Rochambeau, H. de.: The rabbit - husbandry, health and production. FAO Animal Production and Health Series, No 21, 1986.

[17] LPHSI - Livestock and poultry heat stress indices: Agriculture Engineering Guide. Clemson University, Clemson SC., 29634, USA, 1990.

[18] Lukefahr, S. D., Cheeke, P. R.: Rabbit project development strategies in subsistence farming system: Practical consideration. World Animal Reviews, 68, 60-70 (1991).

[19] Makarenko, O. N., Skorik, L. V., Melnichuk, D. A.: The characteristics of nitrogen metabolism in the tissues of rabbits with ammonium toxicosis. Ukrainian Biochemical Journal, 64, 105-109 (1992).

[20] Marai, I. F. M., Habeeb, A. A. M., Gad, A. E.: Rabbits' productive, reproductive and physiological performance traits as affected by heat stress: A review. Livestock Production Science, 78, 71-90 (2002).

[21] Verga Marina: Some characteristics of rabbit behavior and their relationship with husbandry systems. J. Appl. Rabbit Res. 15, 55-63 (1992).

[22] NIOSH - National Institute of Occupational Safety and Health, USA, 2011.

[23] Ogunjimi L, A. O., Oseni, S. O., Lasisi, F.: Influence of temperature-humidity interaction on heat and moisture production in rabbit. Proceeding of $9^{\text {th }}$ World Rabbit Congress, June 10-13, 2008, Verona, Italy, pp. 1579-1583, 2008.

[24] Petkov, G., Kostadinova, G., Stefanova, R., Penev, T., Gercheva, P.: Animal hygiene and ecological assessment of air pollution in a pig-farm. Agr. Sci. and Tech., 2 (3): 143-152 (2010).

[25] Petkov, G., Iliev, A., Kostadinova, G.: Guide for Animal Hygiene Practices. Publishing house, Stara Zagora, pp. 51-54, 1999 (Bg).

[26] Perkins, S.; Lipman, N. S.: Characterization and quantification of microenvironmental contaminants in isolator cages with a variety of contact beddings. Contemporary Topics Lab. Anim. Sci., 173, 96-113 (1995).

[27] Praag, E., Van, Maurer, A., Saarony, T.: Skin Diseases of Rabbits, $1^{\text {st }}$ ed., MediRabbit, 2010, p. 408,.

[28] Preller, L., Heederik, D., Boleij, J. S. M., Vogelzang, P. F. J., Tielen, M. J. M.: Lung function and chronic respiratory symptoms of pig farmers: focus on exposure to endotoxins and ammonia and use of disinfectants. Occupational and Environmental Medicine, 52, 654-60 (1995).

[29] Ramchurn R.: Improved housing conditions for rabbits. Tropical Animal Production, 4 (3), 223-231 (1979). 
[30] REGULATION No. 14: Norms for maximum permissible concentrations of harmful substances in the air of settlements. State Gazette (SG), No. 88 (1997).

[31] REGULATION No. 13: Protect workers from the risks related to exposure to chemical agents at work. $S G$, No. 8 (2003).

[32] REGULATION No. 44: Veterinary medical requirements to animal holding. $S G$, No. 41 (2006).

[33] Schlolaut, W.: Management in rabbit production - graduator for transfer of knowledge into production level. In.:
Proceeding of the $5^{\text {th }}$ Congress of the World Rabbit Science Association, July 25-30, 1992, Oregon, USA, vol. A, pp. 594-614, 1992.

[34] Smith, E., Stockwell, J. D., Schweitzer, I., Langley, S. H., Smith, A. L.: Evaluation of cage microenvironment of mice housed on various types of bedding materials. Contemporary Topics Lab. of Anim. Sci., 43, 12-17 (2004).

[35] Utkin P. G.: Guide for rabbits breeding. Agropromizdat Publ. House, Moscow, 1987, pp. 129-151 (Ru). 
